\title{
PENGEMBANGAN PARIWISATA KABUPATEN KEPULAUAN TALAUD PROVINSI SULAWESI UTARA
}

\author{
Yovanca Koondoko ${ }^{1}$, I Nyoman Darma Putra ${ }^{2}$, Syamsul Alam Paturusi ${ }^{3}$ \\ 1,2,3 Universitas Udayana \\ Email: hkarundeng@gmail.com
}

\begin{abstract}
This article analisys tourism development strategy of Talaud regency, North Sulawesi Province. This regency has a great tourism potential but faces vaious problems. Its tourism potentials is evidenced from the diversity of the natural, culture, and man made tourism attractions. The great tourism potential has not been able to make Talaud widely known by tourists. As the outermost regions, the problems of accessibility are the main obstacles faced by the region of Talaud Islands. Other obstacles such as limited electricity and telecommunication access, and the lack of supporting facilities of tourism activities, have an impact, on the slow development of tourism potential in Talaud. Stages in the research were: described the potentials of tourism, then explained the obstacles that hinder the potential, and finally formulated strategies for the development of tourism potentials. SWOT matrix analysis is used to find the strategies to develop the tourism potential in Talaud. S-O strategy includes the development strategy of attraction. S-T strategy is the institutional strategy. W-O strategy includes the development strategy of public facilities and the supporting facilities at each tourist attraction. W-T strategy includes the making of programs intended for the community participation.
\end{abstract}

Keywords: Talaud Regency, tourism potential, SWOT analisys, development strategy

\begin{abstract}
Abstrak
Artikel ini menganalisis strategi pengembangan pariwisata Kabupaten Kepulauan Talaud, Sulawesi Utara. Daerah ini memiliki potensi wisata yang sangat besar namun menghadapi sejumlah kendala dalam pengembangannya. Hal ini ditunjukan dengan bergamnya potensi wisata yang bersumber dari alam, budaya, dan daya tarik wisata buatan. Besarnya potensi wisata belum mampu membuat nama Talaud dikenal luas oleh wisatawan. Sebagai daerah terluar, persoalan
\end{abstract}


aksesibilitas menjadi kendala utama yang dihadapi oleh daerah Talaud. Kendala lainnya seperti keterbatasan listrik dan telekomunikasi, serta minimnya fasilitas penunjang kegiatan pariwisata, berdampak pada lambatnya perkembangan potensi wisata di Talaud. Tahapan dalam penelitian ini yaitu, mendeskripsikan potensi wisata, kemudian menjelaskan kendala yang menghambat potensi, ketiga memformulasikan strategi pengembangan potensi wisata tersebut. Analisis matriks SWOT digunakan untuk menemukan srategi dalam mengembangkan potensi wisata di Talaud. Strategi S-O diantaranya adalah strategi pengembangan objek wisata. Strategi S-T adalah strategi kelembagaan. Strategi W-O diantaranya adalah strategi pembangunan fasilitas umum dan penunjang di tiap-tiap objek wisata. Strategi W-T di antaranya adalah membuat program yang diperuntukan bagi partisipasi masyarakat.

Kata kunci: Kabupaten Talaud, potensi wisata, SWOT analisi, strategi pengembangan.

\section{Pendahuluan}

Masuknya kawasan perbatasan dalam agenda prioritas pembangunan pemerintahan dewasa ini menjadi salah satu alasan bagi pejabat pemerintah pusat melakukan kunjungan ke pulau-pulau di perbatasan. Selain untuk daerah perbatasan, pemerintah juga memberikan perhatian pada daerahdaerah yang diistilahkan sebagai 3-T: terluar/terdepan, tertinggal, terjauh. Salah satunya adalah Pulau Miangas di Kabupaten Kepuluan Talaud, berlokasi di perbatasan dengan Pulau Mindanao, Filipina. Selama periode 2003-2011, tidak kurang dari empat menteri yang mengadakan kunjungan ke Pulau Miangas (Menteri Negara PDT, Syaifullah Yusuf; Menteri Perikanan dan Kelautan, Rokhmin Dahuri dan penerusnya, Freddy Numberi; dan Menteri Dalam Negeri, Gamawan Fausi), anggota DPR-RI dan DPD-RI, Panglima Kodam VII Wirabuana, serta Gubernur Sulawesi Utara dan pejabat lainnya. Kalangan kampus pun tidak ketinggalan. Universitas Indonesia mengirimkan kurang lebih 70 mahasiswa melakukan KKN selama bulan Juli-Agustus 2009 (Wulandari dan Tangkilisan 2012:7).

Prioritas pemerintah daerah Sulawesi Utara untuk membangun kepariwisataan di Kabupaten Kepulauan Talaud, nyata tertuang dalam Perda No. 1 Tahun 2014 tentang RTRW tahun 2014 - 2034. Kebijakan ini sejalan dengan Perpu No. 50 tahun 2011 yang membahas terkait rancangan utama pengembangan kegiatan pariwisata dengan skala nasional Tahun 2010-2025. Melalui beberapa peraturan tersebut, pemerintah kemudian memasukan 


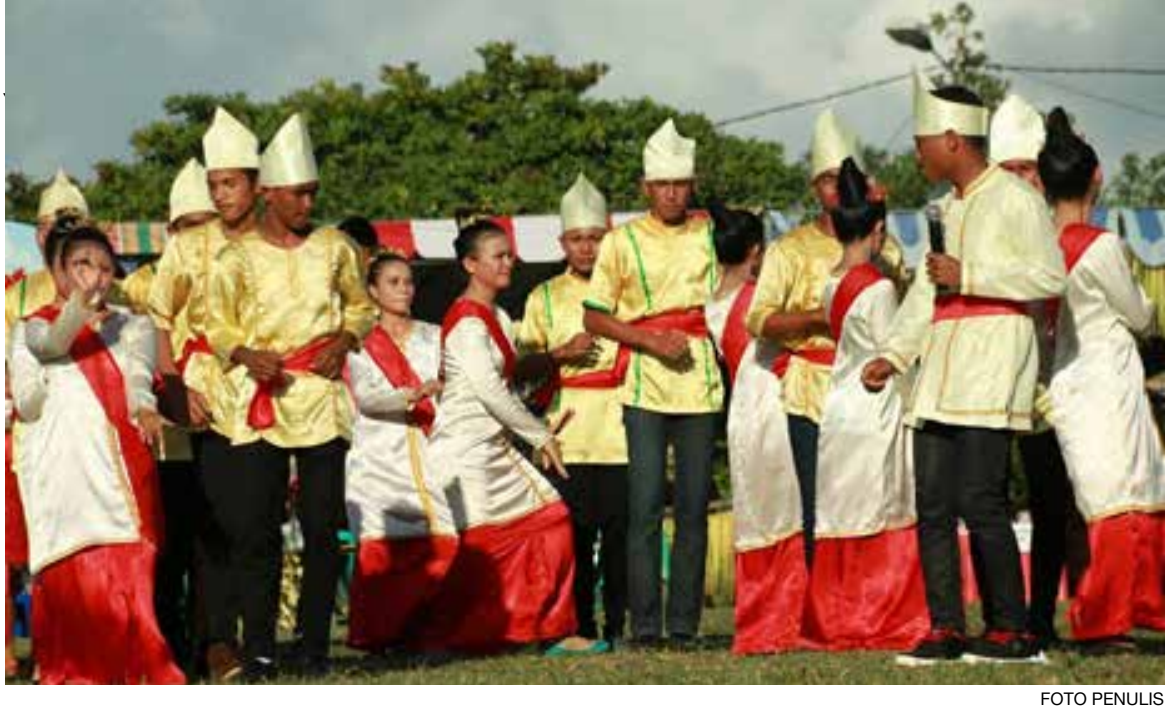

Foto 1. Tari Sasaroho.

Kabupaten Kepulauan Talaud ke dalam 222 Kawasan Pengembangan Pariwisata Nasional (KPPN) dengan menempatkan Manado - Bunaken dan sekitarnya pada nomor urut 41 dari 50 Destinasi Pariwisata Nasional (DPN) yang ada. Industri pariwisata dapat menjadi sumber pendapatan asli daerah (PAD), lapangan kerja, penggerak perputaran perekonomian, dan tentu saja membantu masyarakat mengentaskan kemiskinan (Putra dan Pitana 2010). Dampak positif itu, tentu saja dibarengi dengan dampak sosial budaya yang negatif yang secara sosiologis perlu selalu diatasi untuk menekan hal-hal yang merugikan dan meningkatkan secara optimal hal-hal yang menguntungkan (Pitana dan Gayatri 2005; Pitana dan Surya Diartha 2009)

Paradise atau surga yang oleh masyarakat Kabupaten Kepulauan Talaud disebut Porodisa atau Tanah Porodisa, memiliki banyak potensi wisata. Selain festival adat Mane'e dan Pulau Intata, Kabupaten Kepulauan Talaud juga memiliki Pulau Sara dengan hamparan pasir putih dengan terumbu karang dan ikan terlihat jelas dari permukaan laut, dan sangat cocok untuk diving dan snorkeling. Objek wisata lainnya adalah Gunung Piapi dan Batu Ular di Desa Pulutan, yang sering dikaitkan dengan cerita nenek moyang terkait asal mula terbentuknya Kabupaten Kepulauan Talaud. Budidaya tanaman pisang abaka di Kecamatan Essang, sebagai bahan baku uang kertas dolar. Tari Barek, Tari Sasaroho, Tari Bara, Musik Bambu Entel, tradisi Manami/Maniu.

Meskipun mememiliki tempat-tempat wisata yang indah, serta berpotensi untuk dikembangkan, banyak masyarakat yang masih belum mengetahui daya tarik wisata tersebut. guna memajukan pariwisata di Kabupaten Kepulauan Talaud. Masalah aksesibilitas menjadi kendala utama dari dan menuju tempat wisata pulau ini.

Artikel ini menguraikan potensi dan kendala apa saja yang menyebabkan lambatnya perkembangan pariwisata di Kabupaten Kepulauan Talaud, dengan cara menemukan strategi yang tepat guna mengatasi permasalahan 
lambatnya perkembangan pariwisata tersebut. Tujuan artikel ini untuk mengetahui tiga hal. Pertama, potensi wisata apa saja yang dapat dikembangkan di Kabupaten Kepulauan Talaud. Kedua, kendala yang menjadi penghambat perkembangan potensi wisata di Kabupaten Kepulauan Talaud. Ketiga, bagaimana strategi pengembangan daya tarik wisata di Kabupaten Kepulauan Talaud.

\section{Teori dan Metode}

Teori perencanaan, teori permintaan dan penawaran, serta teori siklus hidup destinasi, adalah beberapa teori yang dipakai dalam penulisan karya ilmiah ini. Pada teori perencanaan menyebutkan bahwa untuk menumbuhkembangkan potensi wisata alam dan budaya, sangat cocok dilakukan di daerah yang tidak memiliki tingkat kepadatan penduduk yang tinggi atau lebih tepatnya di daerah pedesaan dengan keadaan alam yang masih alami, karena beberapa wisatawan cenderung menginginkan tempattempat yang sepi dan sejuk untuk mencari ketenangan (Gunn, 1994:60).

Teori permintaan dan penawaran memandang dari persoalan ekonomi yang menjelaskan bahwa kegiatan pariwisata disebabkan oleh adanya hubungan timbal balik antara wisatawan dengan tempat wisata yang di tuju (Damanik \& Weber, 2006:13).

Menurut Butler (1980:61) dalam teorinya yang berjudul siklus hidup destinasi, menyebutkan bahwa kehidupan suatu daerah tujuan wisata akan mengalami enam tahapan. Salah satu diantara enam tahapan itu adalah bagian keterlibatan yang memberikan pengertian bahwa pada daerah wisata tersebut sudah mulai ada perubahan ke arah yang lebih maju yakni mulai adanya promosi terkait potensi daya tarik wisata daerah tersebut. Tahapan ini sangat cocok dalam mewakili keadaan pariwisata di Talaud.

Data dalam penulisan artikel ini dikumpulkan dari hasil wawancara dengan pegawai di Disbudpar Talaud, Tokoh masyarakat, dan studi dokumen. Penelitian ini berlokasi di dua tempat yaitu, Desa Beo dan Melonguane sebagai Ibukota Kabupaten Kepulauan Talaud Provinsi Sulawesi Utara. Waktu penelitian dimulai pada bulan Juli sampai Agustus 2015 dan dilanjutkan kembali pada bulan Oktober sampai November 2016. Pemilihan lokasi dilakukan dengan sengaja memilih Kabupaten Kepulauan Talaud sebagai tempat penelitian melalui tiga pertimbangan. Pertama adalah satu-satunya wilayah kepulauan di Indonesia yang khas dengan upacara ritual Tradisi Mane'e. Kedua kondisi daerah dengan keadaan alam yang masih alami, belum tersentuh oleh banyak tangan investor/stakeholder, dan belum dikelolanya secara maksimal terkait potensi daya tarik wisata. Ketiga keberadaan lokasi penelitian yang berada dekat dengan tempat tinggal kerabat, sehingga mempermudah penulis untuk melakukan penelitian 


\section{Pembahasan}

Kabupaten Kepulauan Talaud berada di antara Pulau Sulawesi dan Pulau Mindanao Republik Philipina. Talaud terdiri dari tiga pulau besar dan satu pulau kecil. Tiga pulau tersebut adalah Kabaruan, Salibabu, dan Karakelang dan pulau kecil yaitu Kepulauan Nanusa. Melonguane adalah ibukota Kabupaten Kepulauan Talaud, dengan jarak sekitar 271 Mil laut dari kota Manado. Disebut juga daerah maritim dengan luas laut 37.800 persegi, dengan kondisi penduduk berjumlah kurang lebih 300.ooo jiwa dan dikategorikan sebagai masyarakat nelayan dan bertani dengan pendapatan terbesar berasal dari sektor kelautan. Perjalanan dari Manado ke Talaud dapat di tempuh dengan menggunakan transportasi udara dan laut. Jika menggunakan transportasi udara perjalanan dapat di tempuh selama 45 menit dengan pesawat Wing Air sedangkan jika menggunakan transportasi laut perjalanan dapat di tempuh selama 18 jam dengan kapal laut. Pelayanan penerbangan dari Manado-Melonguane (ibukota Kabupaten Kepulauan Talaud) dibuka 7 kali seminggu dan pelayanan keberangkatan kapal laut dibuka 3 kali seminggu baik di pelabuhan Manado maupun di pelabuhan Talaud (Disbudpar Talaud, 2015).

Selain wisata alam sebagai potensi daya tarik terbesar yang dimiliki oleh Kabupaten Kepulauan Talaud, wisata adat dan budaya yang kental yang masih dimiliki oleh masyarakat, juga menjadi daya tarik wisata yang tidak kalah populer. Salah satunya adalah budaya Mane'e yaitu tradisi penangkapan ikan secara tradisional.

\subsection{Potensi Pariwisata Kabupaten Kepulauan Talaud}

Sebagai daerah kepulauan, Talaud memiliki banyak potensi wisata alam pantai, air terjun, dan lanskap lainnya. Berikut diuraikan beberapa yang menonjol.

Pertama, Pulau Intata yaitu pulau tak berpenghuni dengan keindahan pantai, keanekaragaman ikan dan terumbu karang. Pada pulau ini biasanya dilaksanakan festival adat Mane'e. Untuk mengakses Pulau Intata, dapat ditempuh dengan menggunakan speed boat yang berangkat dari pelabuhan Melonguane.

Kedua, Desa Pulutan. Selain menawarkan panorama pedesaan yang sepi dan udara sejuk, di desa ini terdapat Gunung Piapi yaitu gunung tertinggi di Kabupaten Kepulauan Talaud dengan ketinggian kurang lebih 864 m dpl yang sering di jadikan tempat hiking. Objek wisata lainnya adalah Pantai Batu Ular yang sering dikaitkan dengan cerita nenek moyang zaman dahulu, bahwa batu ular dulunya adalah ular naga raksasa yang kalah bertarung dengan dua kesatria Talaud. Kekalahan tersebut menyebabkan isi perut dari ular meledak keluar dan bertaburan di bebatuan pantai.

Ketiga, Pulau Sarra. Pulau ini terdiri dari 2 bagian yaitu Sarra besar dan 


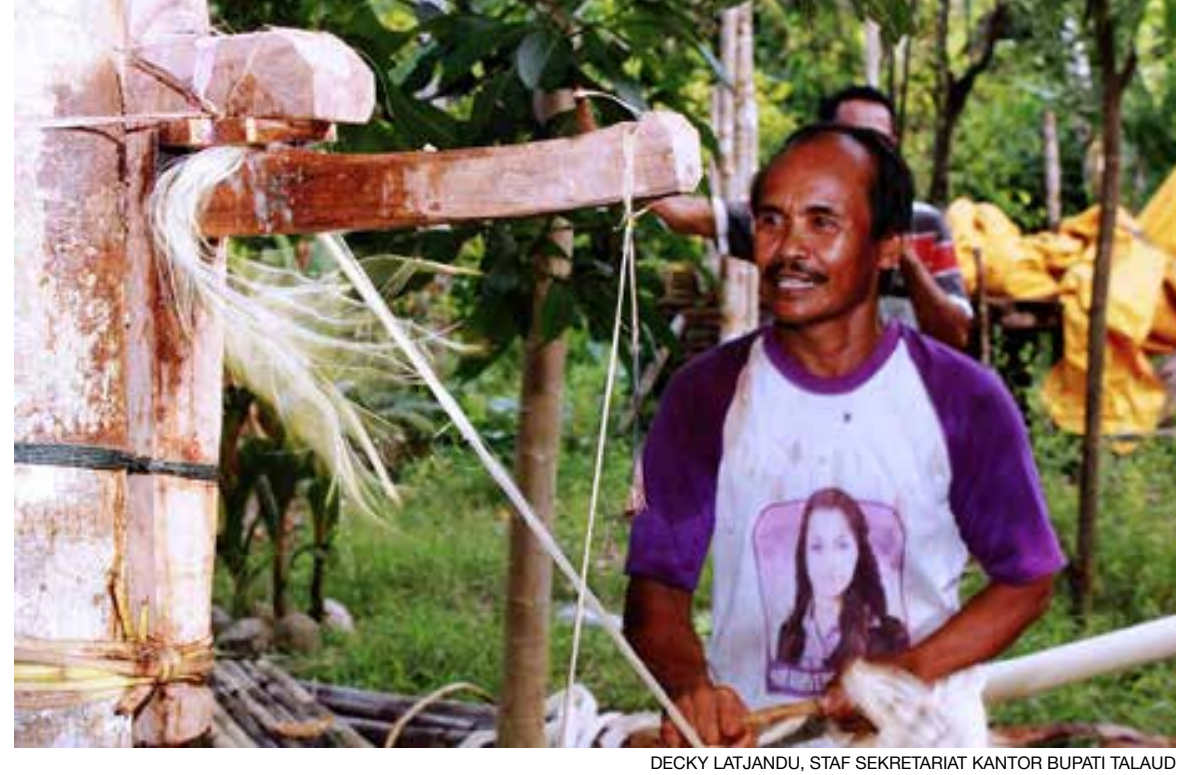

Foto 2. Petani pisang

Sarra kecil dengan luas wilayah secara keseluruhan $\pm 2,03 \mathrm{~km}^{2}$. Aksesibilitas menuju pulau Sarra melalui Pelabuhan Melonguane dan Pelabuhan Lirung. Transportasi yang digunakan adalah speed boat dengan waktu tempuh sekitar 15 menit apabila berangkat dari Pelabuhan Melonguane dan 5 menit apabila berangkat dari Pelabuhan Lirung. Rekreasi bawah air seperti snorkling dan diving sangat cocok dilakukan di tempat ini.

Keempat, Air terjun Ampadoap di Desa Beo. Air terjun dengan debit air melimpah dan dikelilingi hutan hujan tropis yang masih alami. Wisata air terjun ini masuk kedalam salah satu wisata yang sedang dikembangkan oleh pemerintah Kabupaten Kepulauan Talaud.

Kelima, Pantai Tambio'e di Desa Beo. Pantai ini dapat diakses dari Pelabuhan Melonguane dengan waktu tempuh selama 1,5 jam menggunakan mobil dan 15 menit dari Pelabuhan Beo dengan menggunakan bentor. Keindahan pantai yang sudah tertata dengan bangunan fasilitas umum berupa tempat-tempat duduk dan bersantai, menikmati pemandangan matahari terbenam, menambah rasa nyaman selama berada di pantai ini.

Keenam, Penduduk lokal di Kecamatan Esang Kabupaten Kepulauan Talaud, sudah lama memanfaatkan tanaman pisang abaka dalam kehidupan sehari-hari. Awalnya pemanfaatan pisang abaka hanyalah diolah sebagai panganan kecil atau makanan pelengkap saja, nanti pada tahun 2012 setelah dikembangkan lebih lanjut oleh pemerintah daerah setempat, barulah serat tanaman ini mulai di kirim ke negara-negara yang menggunakan mata uang dolar sebagai bahan baku pembuatan uang kertas dolar tersebut.

Ketujuh, tarian tradisional suku Talaud yang sering ditampilkan dalam acara-acara tertentu seperti pada penjemputan tamu (wanita) daerah dengan Tari Sasaroho, sedangkan Tari Bara adalah tari perang yang sering ditampilkan dalam pesta rakyat dan penjemputan tamu (pria) daerah.

Kedelapan, tari tradisional yang masih dipertahankan oleh masyarakat 
berbagai langkah ke arah pengembangan, namun hasilnya belum optimal karena berbagai faktor termasuk aksesibilitas sebagai daerah terluar/terjauh dan juga kualitas jalan yang rusak di berbagai tempat. Tujuan PP No. 24 Tahun 1979 yang memberikan kepercayaan kepada pemda setempat dalam mengelola segala macam bentuk kegiatan pariwisata terkait atraksi wisata yang terjadi pada daerah tersebut.

Mengutip dari hasil wawancara pada 14 Oktober 2016 dengan Kepala Dinas Kebudayaan dan Pariwisata yang juga menjabat sebagai Ketua Dewan Adat di Kabupaten Kepulauan Talaud, Ishak Tamaroba, menyatakan bahwa wisatawan akan banyak berkunjung pada saat penyelenggaraan festival adat seperti Mane'e. Selaras dengan pernyataan di atas, salah seorang staf di dinas pariwisata, Arianto Marunsenge juga menyebutkan bahwa festival Mane'e, sampai saat ini masih didominasi oleh wisatawan lokal.

Berangkat dari dua hasil wawancara di atas, dapat dikatakan bahwa atraksi wisata di Kabupaten Kepulauan Talaud sangat mengandalkan festival Mane'e sebagai tulang punggung pendukung kegiatan kepariwisataan. Sedangkan sebagai warisan budaya dan merupakan upacara yang sakral, festival adat Mane'e hanya diselenggarakan sekali dalam setahun dengan tetap mempertimbangkan faktor cuaca sebagai faktor penentu waktu yang tepat dalam melaksanakan festival adat tersebut.

Atraksi wisata budaya yaitu tradisi Mane'e banyak dihadiri oleh wisatawan yang di dominasi oleh masyarakat lokal. Wawancara pada tanggal 10 Oktober 2016 dengan salah satu warga lokal setempat, Helen Karundeng yang mengatakan bahwa pada saat pelaksanaan upacara adat Mane'e, biasanya bagi warga lokal akan diberikan tumpangan gratis oleh para pemilik kapal untuk di antar ke lokasi pelaksanaan upacara.

Minimnya informasi terkait daya tarik wisata lainnya menjadi salah satu kendala perkembangan potensi wisata. Padahal ada begitu banyak potensi wisata baik wisata alam maupun budaya yang sangat sayang untuk dilewatkan apabila berkunjung ke Kabupaten Kepulauan Talaud.

Faktor kedua yang berpengaruh dalam pengembangan suatu daerah menjadi destinasi wisata adalah aksesibilitas. Berdasarkan wawancara tanggal 16 Oktober dengan salah seorang warga lokal yang juga menjadi pekerja proyek pembangunan jalan, Rommy Wongkar mengatakan bahwa pembangunan jalan di Kabupaten Kepulauan Talaud sudah banyak mengalami perubahan semenjak pertengahan tahun 2015. Akan tetapi, perubahan yang ada hanya terjadi di area-area tertentu saja yakni yang tidak dilewati oleh kendaraan-kendaraan besar pengangkut peralatan dan bahan proyek. Jalan utama dari Melonguane menuju Beo terus mendapat perbaikan karena jalur ini sering dilewati oleh kendaraan-kendaraan proyek. Lain halnya dengan kondisi jalan penghubung antardesa yang agak rusak.

Selain aksesibilitas dari dalam, kendala juga datang dari luar. Persoalan 
transportasi dalam menjangkau daerah di Kabupaten Kepulauan Talaud, masih menjadi kendala bagi wisatawan yang hendak berkunjung. Lamanya waktu tempuh apabila menggunakan kapal laut dan terbatasnya rute penerbangan apabila menggunakan pesawat, serta faktor cuaca masih menjadi salah satu alasan terbesar bagi wisatawan yang ingin berkunjung, (hasil wawancara dengan Helmi Jukes tanggal 26 November 2016).

Faktor ketiga, sarana kepariwisataan seperti hotel, yang berpartisipasi dalam kegiatan wisatawan pada objek wisata yang dikunjungi (Yoeti, 1996: 199). Salah seorang warga yakni Marlon Ngalo dalam wawancara mengatakan bahwa hotel atau penginapan dan rumah makan hanya terdapat pada daerah tertentu saja dan jumlahnya pun masih sangat sedikit (wawancara tanggal 16 Oktober 2016). Daerah-daerah yang dimaksud di antaranya di Ibu Kota Kabupaten yaitu di Melonguane dan di Kecamatan Beoyang memiliki Pelabuhan Laut, komplek perkantoran pemerintah, dan Bandara Udara.

Pada era modern saat ini, sistem telekomunikasi melalui telepon genggam atau handphone sudah menjadi salah satu barang penting dalam melaksanakan kegiatan setiap hari. Handphone (hp) akan sulit digunakan jika tidak mendapat jaringan atau signal pemancar.

Berdasarkan pengalaman pribadi peneliti selama berkunjung Di Kabupaten Kepulauan Talaud jaringan hp apalagi jaringan internet cepat seperti $3 \mathrm{G}$ dan 4G, masih sulit didapatkan. Hal ini membuat sebagian warga yang hendak menggunakan fasilitas jaringan internet untuk berkomunikasi, mencari informasi lewat media sosial, harus mencari posisi yang tepat seperti berdiri di depan halaman rumah atau keluar ke jalan raya, bahkan ada yang sampai memanjat pohon.

Perusahaan Listrik Negara (PLN) sebagai sumber daya listrik utama, memegang peranan penting dalam pengembangan kegiatan pariwisata di Kabupaten Kepulauan Talaud, diantaranya sebagai daya listrik utama bagi warung makan dan penginapan, kegiatan perkantoran pemerintah daerah, fasilitas pelabuhan, pasar, dan pemenuhan kebutuhan rumah tangga. Akan tetapi mengingat Talaud sebagai daerah kepulauan, tentu tidak semua pulau bahkan pulau-pulau kecil dapat dijangkau oleh PLN. Pembangunan Pembangkit Listrik Tenaga Uap menjadi salah satu solusi pemecahan masalah terkait sistem kelistrikan di

Namun berdasarkan pengakuan dari beberapa masyarakat setempat, bahwa ternyata belum semua daerah bisa dijangkau. Contohnya warga di Pulau Karakelang yang belum bisa menikmati cahaya lampu di malam hari (Wawancara dengan Stenly Pulu 02 Februari 2017).

\section{Faktor-faktor yang Mendukung Pengembangan Pariwisata Talaud}

Terlepas dari kelemahan dan hambatan, Talaud memiliki beberapa kekuatan. Kekuatan dalam penelitian ini adalah segala sesuatu yang dapat 
diandalkan dalam mengembangkan segala potensi sebagai daya tarik wisata di Kabupaten Kepulauan Talaud. Pertama adalah Kondisi bentang alam Kabupaten Kepulauan Talaud yang terbilang landai atau datar, sehingga cocok untuk berbagai kegiatan wisata alam, bagus untuk sistem pertanian.

Kedua adalah wilayah penangkapan ikan yang masih luas ditambah dengan hasil ikan yang melimpah. Ketiga memiliki beragam potensi wisata baik alam maupun budaya, contohnya Mane'e sebagai budaya yang unik dan khas Kabupaten Kepulauan Talaud. Berdasarkan wawancara tanggal 14 Oktober dengan Kepala Dinas Kebudayaan dan Pariwisata, Ishak Tamaroba, mengatakan bahwa sampai saat ini festival adat Mane'e, masih menjadi objek wisata andalan di Kabupaten Kepulauan Talaud. Keempat adalah jumlah penduduk dengan usia produktif yang masih tinggi yakni sebesar 95\%, memberikan keuntungan lebih dalam mengelola kegiatan pariwisata di Kabupaten Kepulauan Talaud.

Kelemahan dalam penelitian ini adalah promosi wisata yang belum maksimal oleh pemerintah dan masyarakat terkait, persoalan aksesibilitas yang sangat mempengaruhi keinginan wisatawan dalam berkunjung, sistem transportasi dan komunikasi yang masih kurang bahkan memerlukan pembenahan yang besar, pemberdayaan sumber daya manusia yang masih terbatas dan pengelolaan sarana akomodasi yang masih minim termasuk jasa layanan informasi bagi wisatawan yang masih kurang.

Peluang yang dimiliki oleh Kabupaten Kepulauan Talaud diantaranya adalah sebagai sarana promosi beragam objek wisata, kondisi lahan yang masih luas memberikan peluang dalam pengembangan industry di sector pertanian, melalui pengembangan industri baik di sector pertanian maupun perikanan akan nantinya dapat meningkatkan taraf hidup masyarakat dengan penyerapan tenaga kerja yang lebih besar, pelatihan keterampilan bagi masyarakat, sehingga pada akhirnya potensi wisata di Kabupaten Kepulauan Talaud akan semakin berkembang.

Faktor yang dianggap akan memberikan kerugian bahkan kegagalan di antaranya adalah kondisi Kabupaten Kepulauan Talaud sebagai daerah kepulauan yang landai atau datar, mengancam terjadinya bencana alam yang sulit untuk diprediksi. Selain itu, ancaman seperti pencemaran lingkungan baik di darat ataupun di laut dikarenakan pertumbuhan industri pertanian dan perikanan, pembangunan infrastruktur yang masih lambat, serta kecenderungan masyarakat untuk berimigrasi.

Pada saat berkunjung ke lokasi penelitian, dilakukan wawancara kepada pihak-pihak terkait yakni Kepala Dinas Pariwisata juga selaku Ketua Dewan Adat Kabupaten Kepulauan Talaud, staf dinas pariwisata, tokoh masyarakat, warga lokal dan wisatawan. Selain wawancara, juga dilakukan pengamatan terhadap objek penelitian dalam hal ini adalah segala sesuatu yang menguatkan, melemahkan, memberi peluang dan ancaman terhadap 
pengembangan potensi wisata Kabupaten Kepulauan Talaud menjadi destinasi wisata Provinsi Sulawesi Utara.

Berdasarkan atas hasil kajian dari data-data penelitian dan observasi, maka strategi yang tepat digunakan dalam mengembangkan kegiatan pariwisata di Kabupaten Kepulauan Talaud adalah strategi pengembangan produk wisata dengan jalan memperluas daerah promosi wisata (Umar, 2005: 46). Pemilihan pengembangan produk wisata sebagai strategi untuk mengembangkan potensi wisata di Kabupaten Talaud, dilatarbelakangi oleh kesenjangan antar objek wisata yang menjadi produk wisata. Ada begitu banyak objek wisata baik wisata alam dan budaya, tetapi hanya festival adat Mane'e yang di minati oleh wisatawan lokal dan mancanegara.

Berdasarkan kekuatan serta peluang yang ada dan dimiliki oleh Kabupaten Kepulauan Talaud, diantaranya: berbagai potensi wisata menarik mulai dari pesona alam sampai pada budaya, budaya yang khas satu-satunya di Indonesia bahkan dunia yakni budaya Mane'e, Keindahan pantai dengan pasir putih yang cocok untuk diving dan snorkeling, serta tingkat keamanan pada masing-masing objek wisata yang terjaga, masuk dalam kawasan Taman Nasional Bunaken (TNB), promosi pariwisata yang semakin diperbaharui atau dikembangkan, dan penyerapan tenaga kerja.

Strategi yang menggunakan kekuatan untuk mengatasi ancaman, yaitu, minimnya sarana dan pra-sarana dalam mendukung kegiatan pariwisata, listrik, jalan, telepon, toilet, masih kurang bahkan banyak yang sudah rusak, kurangnya perhatian dari pihak pemerintah setempat dalam membangun infrastruktur serta pengembangan objek wisata yang sudah ada (objek wisata berupa peninggalan sejarah) dan meningkatkan kualitas SDM, serta bencana alam yang tidak dapat di prediksi dan bisa datang kapan saja.

Strategi S-T dimana strategi yang dihasilkan dalam penelitian ini adalah strategi kelembagaan guna menerbitkan peraturan-peraturan dalam melaksanakan kegiatan kepariwisataan dan melakukan perbaikan di bidang sarana terutama infrastruktur dasar.

Strategi yang menggunakan peluang untuk mengurangi kelemahan, seperti: aksesibilitas dari dan menuju objek wisata yang masih sulit, pariwisata di Kabupaten Kepulauan Talaud yang belum terlalu dikenal luas oleh masyarakat baik dalam maupun luar negeri, minimnya sarana dan prasarana yang tersedia pada masing-masing objek wisata, objek wisata yang kurang terawat, jalan, listrik, telekomunikasi sebagai infrastruktur utama, masih banyak yang rusak bahkan ada yang belum di aspal, sulit mendapatkan jaringan internet, tidak ada listrik di malam hari pada daerah-daerah tertentu, keterbatasan transportasi umum, Kualitas SDM yang masih minim.

Mengurangi kelemahan sangat penting dalam memajukan kegiatan pariwisata guna mendukung pengembangan Kabupaten Kepulauan Talaud sebagai destinasi wisata Provinsi Sulawesi Utara. Strategi W-O yang dihasilkan 
dari pemanfaatan peluang yakni perkembangan teknologi, pembangunan fasilitas umum dan fasilitas penunjang kegiatan pariwisata dan penambahan sarana dan prasarana dalam bidang pendidikan

Strategi yang menghindari ancaman dengan mengurangi kelemahan, strategi yang dihasilkan yaitu, membuat program yang diperuntukan bagi masyarakat, memberdayakan masyarakat dalam mengelola kegiatan pariwisata, serta pemberdayaan masyarakat lokal yakni tata cara perilaku masyarakat yang ramah dan santun dan diharapkan meninggalkan kesan yang baik bagi wisatawan yang berkunjung ke objek-objek wisata di Kabupaten Kepulauan Talaud.

Kurangnya pengetahuan anak-anak muda terkait budaya asli Kabupaten Kepulauan Talaud, seperti tari-tarian dan penggunaan alat musik tradisional daerah. Proses regenarasipun mulai memudar oleh karena kurangnya minat para generasi penerus yaitu anak-anak muda di Kabupaten Kepulauan Talaud yang lebih memilih bermigrasi ke luar daerah. Oleh karena itu, dapat disiasati dengan memberikan pelatihan seni tari dan alat musik ke dalam kurikulum pengajaran sekolah melalui kegiatan tambahan atau extrakurikuler.

\section{Simpulan}

Berdasarkan analisis di atas, dapat disimpulkan tiga hal berikut sesuai dengan strategi pengembangan Kabupaten Kepulauan Talaud sebagai destinasi wisata.

Pertama, potensi wisata di Kabupaten Kepulauan Talaud berasal dari sumber daya alam yaitu, Pulau Sarra, Pulau Intata, Desa Pulutan, Pantai Tambio'e, Air terjun Ampadoap. Sumber daya buatan yaitu, Budidaya Pisang Abaka, Tari Sasaroho, Tari Bara, Musik Bambu Entel, Musik Tambor, Tradisi Mane'e/Manami/Maniu. Terdapat dua objek wisata yang sedang dikembangkan oleh pemerintah daerah Kabupaten Kepulauan Talaud yaitu Pantai Tambio'e dan Air terjun Ampadoap yang berlokasi di Desa Beo Kecamatan Beo.

Kedua, meskipun memiliki beragam potensi dan terbilang baik untuk dikembangkan, tidak langsung membuat Kabupaten Kepulauan Talaud menjadi salah satu destinasi wisata Provinsi Sulawesi Utara. Hal ini dikarenakan oleh beberapa kendala yaitu, keterbatasan frekuensi dan rute penerbangan serta jadwal pelayaran dari dan menuju Kabupaten Kepulauan Talaud, minimnya transportasi di dalam daerah Talaud, masalah pembangunan infrastruktur dasar (jalan, listrik, telekomunikasi) yang tidak merata di setiap daerah, kurangnya kesadaran masyarakat dalam memelihara fasilitas-fasilitas umum (toilet, tempat sampah, saluran pengairan dan irigasi) yang sudah disediakan oleh pemerintah, kurangnya fasilitas penunjang kegiatan pariwisata seperti jasa layanan akomodasi yang masih kurang, minimnya penyedia informasi terkait objek wisata bagi 
wisatawan serta minimnya lampu jalan atau penerangan pada objek wisata, belum tersedianya agen wisata sebagai salah satu organisasi kepariwisataan yang menunjang kegiatan pariwisata Kabupaten Kepulauan Talaud.

Ketiga, beberapa kendala di atas memerlukan strategi yang tepat guna memecahkan bermacam-macam kendala yang ada melalui analisis dan matriks SWOT. Strategi yang didapatkan berupa: perbaikan dan penambahan infrastruktur dasar seperti, pengaspalan pada jalan-jalan utama yang menghubungkan setiap desa pada satu kecamatan dan antar kabupaten, lampu jalan, pembangunan dan perbaikan dermaga serta tempat peristirahatan pada objek wisata secara keseluruhan di daerah Kabupaten Kepulauan Talaud, termasuk pulau tidak berpenghuni (Pulau Sarra, Pulau Intata). Upaya penyediaan listrik khususnya bagi masyarakat di pelosok desa (Pulau Kakorotan, Pulau Karakelang-Kecamatan Nanusa), dan perbaikan jaringan telekomunikasi. Penyediaan tempat sampah dan toilet serta konter informasi yang mutlak perlu ada pada setiap objek wisata. Peningkatan jasa layanan akomodasi pada hotel, penginapan, tempat makan, penambahan rute dan waktu penerbangan dan perbaikan layanan dalam pelayaran kapal laut dari dan menuju ke Kabupaten Kepulauan Talaud, serta penyediaan jasa layanan organisasi kepariwisataan yang nantinya mengkoordinir kegiatan pariwisata para pengunjung selama berada di Kabupaten Kepulauan Talaud.

\section{Ucapan Terima Kasih}

Dalam kesempatan ini, penulis mengucapkan terimakasih yang sebesarbesarnya kepada Tuhan YME atas tuntunan-Nya penulis boleh menyelesaikan tulisan karya ilmiah ini. Tidak lupa pula penulis berterimakasih kepada Prof. Dr. I Nyoman Darma Putra, M.Litt. selaku Pembimbing I, Prof. Dr. Ir. Syamsul Alam Paturusi, MSP. selaku Pembimbing II, serta Prof. Ir. M. S. Mahendra, M. App. Sc., Ph. D., Prof. Dr. I Nyoman Kutha Ratna, SU., Dr. Ir. I Made Adhika, MSP. atas waktu untuk bimbingan dan memberikan arahan selama penulisan karya ilmiah ini. Ucapan terimakasih juga kepada Ishak Tamaroba, S.Ap selaku Kepala Dinas Kebudayaan dan Pariwisata Kabupaten Kepulauan Talaud, atas kesempatan bagi penulis melakukan penelitian di Melonguane dan Desa Beo, Ny. Tuange selaku Ibu Wakil Bupati, atas waktu untuk berdiskusi singkat terkait program pemerintah dalam pengembangan pariwisata Kabupaten Kepulauan Talaud, Marlon Ngalo atas informasi yang telah diberikan kepada penulis.

\section{Daftar Pustaka}

BPS Kabupaten Kepulauan Talaud. 2016. "Kondisi Sosial Budaya Penduduk", http://talaudkabs.go.id/index.php/pencarian?keywordforsearching $=$ Talaud\&yt $3=$ Cari\&page $=4 \cdot \mathrm{html}$ Diakses 29/12/2016

Butler, Richard. W. 2004. "The Tourism Area Life Cycle in the Twenty-First Century"., 
A Companion to Tourism. Hlm. 159-170. Malden: Blackwell.

Damanik, J. \& Weber, F. 2006. Manajemen Destinasi Pariwisata. Yogyakarta: Kepel Press

Djaenuri, A. \& Enceng, D. 2012. Sistem Pemerintahan Daerah. Banten: Universitas Terbuka.

Gunn, A. 1994. Tourism Planning: Basics, Concepts, Cases. New York: Routledge. Inskeep, E. 1991. Tourism Planning an Integrated and Sustainable Development Approach. New York: Van Nostrand Reinhold.

Koentjaraningrat. 1993. Metode-Metode Penelitian Masyarakat. Jakarta: PT. Gramedia Pustaka Utama.

Kusdiantoro, H. 1996. Perencanaan Pengembangan Destinasi Pariwisata. Jakarta: UI.

Liamputtong, P. 2009. Qualitative Data Analysis: Conceptual and Practical Considerations". Health Promotion Journal of Australia Vol 7 (6). hlm 502-522.

Moleong, L. 2007. Metodologi Penelitian Kualitatif. Bandung: PT. Remaja Rosdakarya Offset.

Paturusi, Syamsul Alam. 2008. Perencanaan Kawasan Pariwisata. Denpasar: Udayana University Press.

Peraturan Daerah Sulawesi Utara Nomor 1 Tahun 2014 Tentang Rencana Tata Ruang Wilayah Provinsi Sulawesi Utara Tahun 2014 - 2034

Peraturan Pemerintah Nomor 50 Tahun 2011 Tentang Rencana Induk Pembangunan Kepariwisataan Nasional Tahun 2010 - 2025.

Pitana, I Gde dan Putu G. Gayatri. 2005. Sosiologi Pariwisata. Yogyakarta: Andi.

Pitana, I Gde dan Ketut Surya Diarta. 2009. Pengantar Ilmu Pariwisata. Yogyakarta: Andi.

Putra, I Nyoman Darma dan I Gde Pitana. 2010. Pariwisata Pro-Rakyat Meretas Jalan Mengentaskan Kemiskinan di Indonesia. Jakarta: Kementerian Kebudayaan dan Pariwisata.

Pusat Ensiklopedi Berbahasa Indonesia. 2016. "Kabupaten Kepulauan Talaud”, : http://13.silaturahim.web.id/ind/1812-1710/Kepulauan-Talaud-SulawesiUtara_28299_up45_13-silaturahim.html Diakses 06/o1/2017

Rangkuti, F. 2008. Analisis SWOT Teknik Membedah Kasus Bisnis. Jakarta: PT. Gramedia Pustaka Utama.

Tahir, M. \& Ramli, AT. 2010. Pembangunan Masyarakat Desa dan Kota. Banten: Universitas Terbuka.

Undang-Undang No. 10 Tahun 2009 Tentang Kepariwisataan

Undang-Undang No.8 Tahun 2002 Tentang Pembentukan Kabupaten Kepulauan Talaud di Provinsi Sulawesi Utara

Undang-Undang Nomor 29 Tahun 1959 Tentang Pembentukan Daerah-daerah Tingkat II di Sulawesi

Wulandari, T., Ulaen, A. \& Tangkilisan, Y. 2012. Sejarah Wilayah Perbatasan Dua Nama Satu Juragan. Depok: Gramata Publishing. 


\section{Profil Penulis}

Yovanca Yully Feniaty Koondoko, lahir di Manado, 13 Juli 1990. Menyelesaikan program studi Diploma III di Politeknik Negeri Manado 2011 dengan gelar A.Md.Par. Diploma IV Program Studi Manajemen Bisnis Pariwisata di Politeknik Negeri Bali, Tahun 2013. Program Magister Pariwisata Universitas Udayana Bali Tahun 2017. Email: hkarundeng@gmail.com

I Nyoman Darma Putra adalah guru besar Fakultas Ilmu Budaya dan Ketua Program Studi Magister Kajian Pariwisata, Universitas Udayana. Darma menulis beberapa artikel di jurnal internasional dan beberap buku biografi tokoh pariwisata Bali, serta menyunting beberapa buku, termasuk Pariwisata Berbasis Masyarakat Model Bali (2015) dan bersama Siobhan Campbell mengedit buku Recent Developments in Bali Tourism: Culture, Heritage, and Landscape in an Open Fortress (2015). Bersama Diah Sastri Pitanatri, Darma menulis buku Wisata Kuliner, Atribut Baru Destinasi Ubud (2016). Email: idarmaputra@yahoo.com

Syamsul Alam Paturusi, adalah Guru Besar Perancangan Kota pada Jurusan Arsitektur, Fakultas Teknik Unud dan dosen Prodi Magister Kajian Pariwisata, saat ini menjabat sebagai sekretaris program studi Magister Kajian Pariwisata, Universitas Udayana. Selain itu, beliau juga aktif mengajar sebagai dosen pada S1 dan S2 Teknik Arsitektur Unud; S3- Pariwisata, Unud; dan S2-S3 Ilmu Lingkungan, Unud. Sarjana (S1) di Arsitektur Universitas Hasanuddin, Makassar, jenjang Magister (S2) di PWK ITB, Bandung, dan jenjang Doktor ( 33 ) di Université de Pau et des Pays de l'Adour, Prancis. Email: syamsul_alam_paturusi@yahoo.fr 